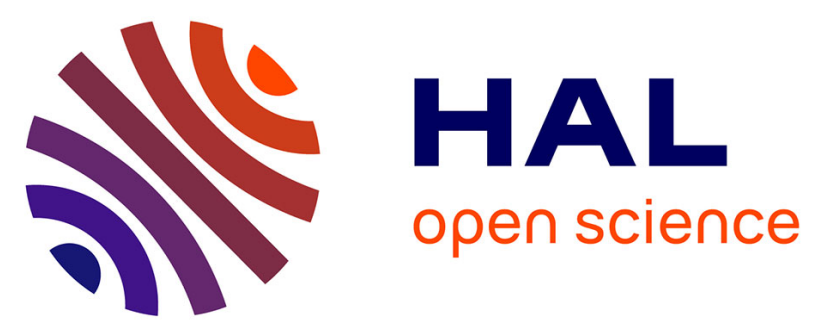

\title{
Initial results in the development of a reporter cell line for toxicology studies at gene expression level: activation of the electrophile-responsive element by copper and methyl parathion
}

Daniela Volcan Almeida, Gilma Santos Trindade, Laura A. Geracitano, Daniela Martí Barros, José Maria Monserrat, Luis Fernando Marins

\section{To cite this version:}

Daniela Volcan Almeida, Gilma Santos Trindade, Laura A. Geracitano, Daniela Martí Barros, José Maria Monserrat, et al.. Initial results in the development of a reporter cell line for toxicology studies at gene expression level: activation of the electrophile-responsive element by copper and methyl parathion. Marine Environmental Research, 2008, 66 (1), pp.158. 10.1016/j.marenvres.2008.02.075 . hal-00563029

\author{
HAL Id: hal-00563029 \\ https://hal.science/hal-00563029
}

Submitted on 4 Feb 2011

HAL is a multi-disciplinary open access archive for the deposit and dissemination of scientific research documents, whether they are published or not. The documents may come from teaching and research institutions in France or abroad, or from public or private research centers.
L'archive ouverte pluridisciplinaire HAL, est destinée au dépôt et à la diffusion de documents scientifiques de niveau recherche, publiés ou non, émanant des établissements d'enseignement et de recherche français ou étrangers, des laboratoires publics ou privés. 


\section{Accepted Manuscript}

Initial results in the development of a reporter cell line for toxicology studies at gene expression level: activation of the electrophile-responsive element by copper and methyl parathion

Daniela Volcan Almeida, Gilma Santos Trindade, Laura A. Geracitano, Daniela Martí Barros, José Maria Monserrat, Luis Fernando Marins

PII:

S0141-1136(08)00076-7

DOI: 10.1016/j.marenvres.2008.02.075

Reference: MERE 3222

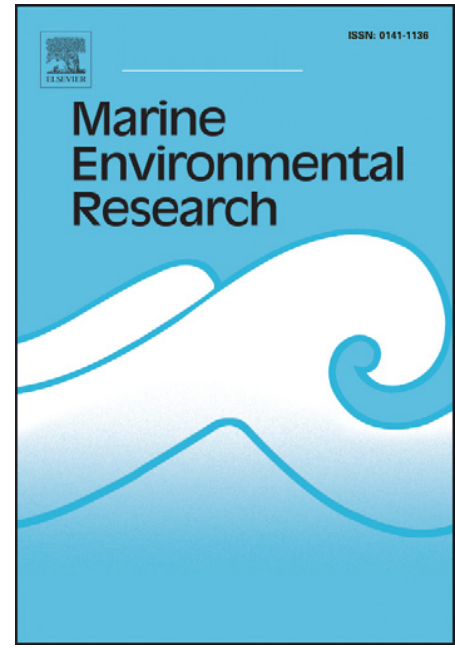

To appear in:

Marine Environmental Research

Please cite this article as: Almeida, D.V., Trindade, G.S., Geracitano, L.A., Barros, D.M., Monserrat, J.M., Marins, L.F., Initial results in the development of a reporter cell line for toxicology studies at gene expression level: activation of the electrophile-responsive element by copper and methyl parathion, Marine Environmental Research (2008), doi: 10.1016/j.marenvres.2008.02.075

This is a PDF file of an unedited manuscript that has been accepted for publication. As a service to our customers we are providing this early version of the manuscript. The manuscript will undergo copyediting, typesetting, and review of the resulting proof before it is published in its final form. Please note that during the production process errors may be discovered which could affect the content, and all legal disclaimers that apply to the journal pertain. 


\title{
Initial results in the development of a reporter cell line for
}

\section{toxicology studies at gene expression level: activation of the}

\section{electrophile-responsive element by copper and methyl parathion}

\author{
Daniela Volcan Almeida ${ }^{a}$, Gilma Santos Trindade ${ }^{\text {a,b }}$, Laura A. Geracitano ${ }^{\text {a }}$, \\ Daniela Martí Barros a,b, José Maria Monserrat ${ }^{\text {a,b }}$, Luis Fernando Marins a,b,* \\ ${ }^{a}$ Programa de Pós-graduação em Ciências Fisiológicas: Fisiologia Animal Comparada, Fundação \\ Universidade Federal do Rio Grande, CP 474, 96201-900, Rio Grande, RS, Brazil \\ ${ }^{b}$ Departamento de Ciências Fisiológicas, Fundação Universidade Federal do Rio Grande, CP 474, 96201 - \\ 900, Rio Grande, RS, Brazil.
}

\begin{abstract}
Induction of many genes encoding detoxifying enzymes and antioxidant proteins is mediated through a common mechanism, which is controlled by electrophile responsive elements (EpRE) within the regulatory region of those genes. Copper and methyl parathion are environmental pollutants known to induce the expression of EpRE-mediated genes. In order to evaluate the molecular response triggered by these pollutants, a stable cell line was produced, which carries a transgene comprised of the green fluorescent protein (GFP) reporter gene under transcriptional control of the mouse glutathione-S-transferase (gst 1 )
\end{abstract}


electrophile responsive element fused to the mouse metallothionein ( $m t 1)$ minimal promoter. The rat HTC hepatoma cells were transfected with the EpREmt-GFP construct and successfully selected with G418 antibiotic. EpREmt-GFP HTC cells were treated with 0.002mg.L $\mathrm{L}^{-1}, 0.02 \mathrm{mg} . \mathrm{L}^{-1}, 0.2 \mathrm{mg} . \mathrm{L}^{-1}$ and $2 \mathrm{mg} . \mathrm{L}^{-1}$ copper sulfate and $0.001 \mathrm{mg} . \mathrm{L}^{-1}, 0.01$ mg. $\mathrm{L}^{-1}, 0.1 \mathrm{mg} . \mathrm{L}^{-1}$ and $1 \mathrm{mg} . \mathrm{L}^{-1}$ methyl parathion for $48 \mathrm{~h}$. GFP expression was directly quantified in living cells using a microplate fluorimeter. GFP expression was significantly increased in higher concentrations of both pollutants, showing a 1.80 - and 2.58 -fold induction of GFP at $2 \mathrm{mg}$ copper. $\mathrm{L}^{-1}$ and $1 \mathrm{mg}$ methyl parathion. $\mathrm{L}^{-1}$, respectively $(p<0.01)$. The results obtained in the present study demonstrate that the EpREmt-GFP HTC cell line can be an interesting model for further development for the study of the cellular response to aquatic pollutants as well as a new tool for environmental monitoring at the molecular level.

Keywords: Electrophile response element; Green fluorescent protein; Hepatoma cells; Copper; Methyl parathion.

Corresponding author: E-mail address: dqmluf@furg.br (L.F. Marins)

Electrophile responsive elements (EpRE) are within the regulatory region of a number of genes involved with xenobiotic metabolism and antioxidant defense. These include NAD(P)H:quinone oxidoreductase (NQO), glutathione S-transferase Ya subunit (GST Ya), heme oxygenase 1 (HO-1), and $\gamma$-glutamylcysteine synthetase (GCL) (for review see Jaiswal, 2004). EpRE core sequence (5'-TMAnnRTGAYnnnGCR-3') was 


\section{ACCEPTED MANUSCRIPT}

characterized by defining regions of the sequence required for basal and xenobiotic inducible expression (Rushmore et al., 1991). Copper and methyl parathion are pollutants capable of generating oxidative stress in zebrafish cells and initiating the transcription of an EpRE-regulated reporter gene (Carvan III et al., 2001). The objective of the present study was to create and validate a stable reporter cell line using green fluorescent protein (GFP) expression as a reporter of EpRE-mediated transcriptional activation. A stable cell line was produced which carries a transgene comprised of the GFP reporter gene under transcriptional control of the mouse glutathione-S-transferase ( $g s t 1)$ electrophile-responsive element fused to the mouse metallothionein ( $m t 1)$ minimal promoter. The cells used in the present study were a rat hepatoma line (HTC) obtained from the Rio de Janeiro Cell Bank (Brazil) and grown in RPMI 1640 (Gibco) medium supplemented with sodium bicarbonate (0.2 g/L), L-glutamine (0.3 g/L), HEPES $(25 \mathrm{mM})$ and $\beta$-mercaptoethanol $\left(5 \times 10^{-5} \mathrm{M}\right)$, with $10 \%$ fetal bovine serum (Gibco), $100 \mathrm{IU} / \mathrm{ml}$ penicillin and $100 \mu \mathrm{g} / \mathrm{ml}$ streptomycin (Gibco), in cell culture flasks, at $37^{\circ} \mathrm{C}$. In order to create the stably transfected EpRE-GFP reporter cell lines, $5 \times 10^{5}$ cells were transfected with $5 \mu \mathrm{g}$ of the EpREmt-GFP construct and $25 \mu \mathrm{g}$ DOTAP cationic lipid (Acros) in $2 \mathrm{~mL}$ serum-free RPMI medium and incubated at $37{ }^{\circ} \mathrm{C}$ for $24 \mathrm{~h}$. The medium was then replaced with $2 \mathrm{~mL}$ RPMI medium and geneticin (500 $\mu \mathrm{g} / \mathrm{mL}$; Gibco) was added after $48 \mathrm{~h}$. Presence of the transgene in the cells was verified by PCR with transgene-specific primers (RV3 - 5' CGGAATTCCTAGCAAAATAGGCTGTCCC-3' and SV40-PA - $\quad$ 5' ACTGCGGCCCGTAAGATACATTGATGA-3'). For model validation, the EpREmt-GFP HTC cells were plated at a concentration of $1 \times 10^{6}$ cells/well in a 24 -well plate and were treated with $0.002 \mathrm{mg} . \mathrm{L}^{-1}, 0.02 \mathrm{mg} . \mathrm{L}^{-1}, 0.2 \mathrm{mg} . \mathrm{L}^{-1}$ and $2 \mathrm{mg} . \mathrm{L}^{-1}$ copper sulfate and 0.001 


\section{ACCEPTED MANUSCRIPT}

mg. $\mathrm{L}^{-1}, 0.01 \mathrm{mg} . \mathrm{L}^{-1}, 0.1 \mathrm{mg} . \mathrm{L}^{-1}$ or $1 \mathrm{mg} . \mathrm{L}^{-1}$ methyl parathion for $48 \mathrm{~h}$. The compounds were dissolved in water (copper) or acetone (methyl parathion) and added in a final concentration of $0.01 \%(\mathrm{v} / \mathrm{v})$ in the cell culture medium. The concentrations of $0.02 \mathrm{mg} . \mathrm{L}^{-1}$ and $0.01 \mathrm{mg} . \mathrm{L}^{-1}$ indicated maximum values permitted by the Brazilian legislation in freshwater for copper and methyl parathion, respectively. Controls were treated with solvents (water for copper and acetone for methyl parathion). GFP expression was directly quantified in living cells using a microplate fluorimeter (Victor 2, Perkin Elmer) with excitation/emission at $485 \mathrm{~nm} / 530 \mathrm{~nm}$. GFP expression values were normalized to total cell number. Fluorescence data were subjected to an analysis of variance (ANOVA). Post-hoc comparisons were made by Tukey's test and all statistical tests used fixed type I error of $5 \%(\alpha=0.05)$. After selection with G418 antibiotic, the cells were subjected to genomic DNA extraction (Sambrook et al., 1989) and PCR analysis, which confirmed the presence of the transgene. For validation of the model, the stable cell lines were exposed to the pollutants at the concentrations cited above and the GFP expression visualized by epifluorescence microscopy (Fig. 1). The results of GFP fluorimeter quantification showed a 1.8-fold induction of GFP at $2 \mathrm{mg}$ copper. $\mathrm{L}^{-1}$ (Fig. $2 \mathrm{~A}, \quad p<0.01$ ) and 2.58 times at $1 \mathrm{mg}$ methyl parathion. $\mathrm{L}^{-1}$ over controls (Fig. $2 \mathrm{~B}, p<0.01$ ). These results indicate an EpRE induction only at concentrations that exceed 100 times the value permitted by the Brazilian legislation. However, copper concentration up to $216 \mathrm{mg} \cdot \mathrm{L}^{-1}$ has been found in aquatic environment at Southern Brazil (Niencheski and Baumgarten, 2000), which makes this model suitable for this level of contamination. In terms of comparison between the pollutants studied here, Carvan III et al. (2001) also verified a larger induction capacity for methyl parathion when compared to copper, corroborating our results. Profiles showing induction of GFP reporter gene expression were described by Zhu and Fahl (2000). These 


\section{ACCEPTED MANUSCRIPT}

authors have considered that EpRE-mediated gene activation is related to cellular detoxification processes. Even though we have demonstrated that EpRE can be induced in HTC cells by high concentrations of copper and methyl parathion, a high level of basal EpRE-GFP induction was also observed in this cellular type (Fig. 1). In fact, it is known that genes involved with xenobiotic metabolism and antioxidant defense are highly expressed in tumoral cells (for review see Nair et al., 2007). This could explain the lack of significant differences at lower pollutant concentrations (Fig. 2). In addition, both pollutants used here could be chelated or complexed with other components present in the medium and thus unavailable to the cells. An interesting perspective of the present study is the development of new reporter cell lines of non-tumoral origin, which are currently underway in our laboratory. The employment of such cell lines as environmental monitoring models through utilization of transgenes constituted by pollutant responsive elements directing reporter gene expression could compose a sensitive, low-cost and practical method for biological monitoring of aquatic pollution. In summary, the initial results obtained in the present study are promising and have stimulated further development of in vitro models as tools for the study of cellular response to aquatic pollutants.

\section{Acknowledgments}

The authors would like to thank to Maira Proietti for valuable corrections of the manuscript. This work was supported by FAPERGS (Proc. N. 0412405). D.V. Almeida and L.A. Geracitano, a graduate student and post-doctoral fellow, respectively, were financed by CAPES. J.M. Monserrat and D. Martí Barros are research fellows from CNPq. 


\section{ACCEPTED MANUSCRIPT}

\section{References}

Carvan III, M.J., Sonntag, D.M., Cmar, C.B., Cook, R.S., Curran, M.A., and Miller, G.L. (2001). The Science of the Total Environment, 274, 183-196.

Jaiswal, A.K. (2004). Free Radical Biology \& Medicine, 36, 1199-1207.

Nair, S., Li, W., and Kong, A. T. (2007). Acta Pharmacologica Sinica, 28, 459-472.

Niencheski, L.F., and Baumgarten, M.G.Z. (2000). Aquatic Ecossystem Health and Management, 3, 515-520.

Rushmore, T.H., Morton, M.R., and Pickett, C.B. (1991). Journal of Biological Chemistry, 266, 11632-11639.

Sambrook, J., Fritsch, E.F., and Maniatis, T. (1989). Molecular Cloning: A Laboratory Manual. 2nd edition. Cold Spring Harbor Laboratory Press, Cold Spring Harbor, New York.

Zhu, M., and Fahl, W.E. (2000). Analytical Biochemistry, 287, 210-217. 


\section{Figure captions}

Fig. 1. Green fluorescence protein (GFP) expression visualized using an epifluorescence microscope ( $\times 400$ magnification). Cells were treated with $0.002 \mathrm{mg} . \mathrm{L}^{-1}(\mathrm{C} 2), 0.02 \mathrm{mg} . \mathrm{L}^{-}$ ${ }^{1}(\mathrm{C} 3), 0.2 \mathrm{mg} . \mathrm{L}^{-1}(\mathrm{C} 4)$ and $2 \mathrm{mg} . \mathrm{L}^{-1}(\mathrm{C} 5)$ copper sulfate and $0.001 \mathrm{mg} . \mathrm{L}^{-1}(\mathrm{C} 2), 0.01 \mathrm{mg} . \mathrm{L}^{-}$ ${ }^{1}(\mathrm{C} 3), 0.1 \mathrm{mg} \cdot \mathrm{L}^{-1}(\mathrm{C} 4)$ and $1 \mathrm{mg} . \mathrm{L}^{-1}(\mathrm{C} 5)$ methyl parathion for $48 \mathrm{~h}$. Controls (C1) were treated with solvents (water for copper and acetone for methyl parathion). a. phase-contrast; b. fluorescence.

Fig. 2. Green fluorescence protein (GFP) expression in EpREmt-GFP HTC cell line. Cells were treated with copper sulfate (A) and methyl parathion (B) for $48 \mathrm{~h}$. Controls were treated with solvents (water for copper and acetone for methyl parathion). The results are expressed in RFU (relative fluorescence units) normalized by total cell number. Induction is reported as the mean expression \pm S. E.; $(*)$ indicates significant difference $(n=3) p<0.01$. 


\section{ACCEPTED MANUSCRIPT}

Figure 1

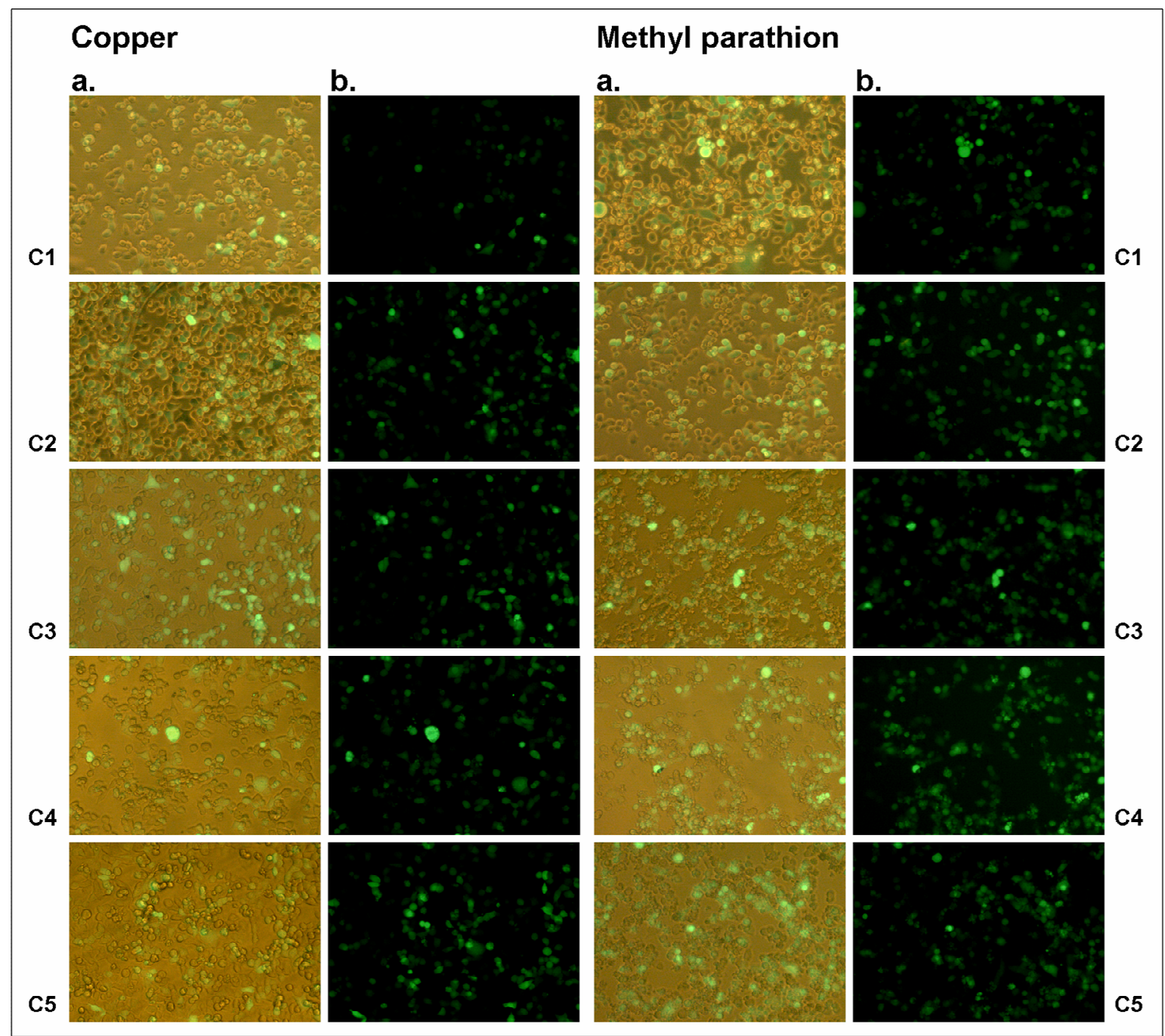


Figure 2

A.

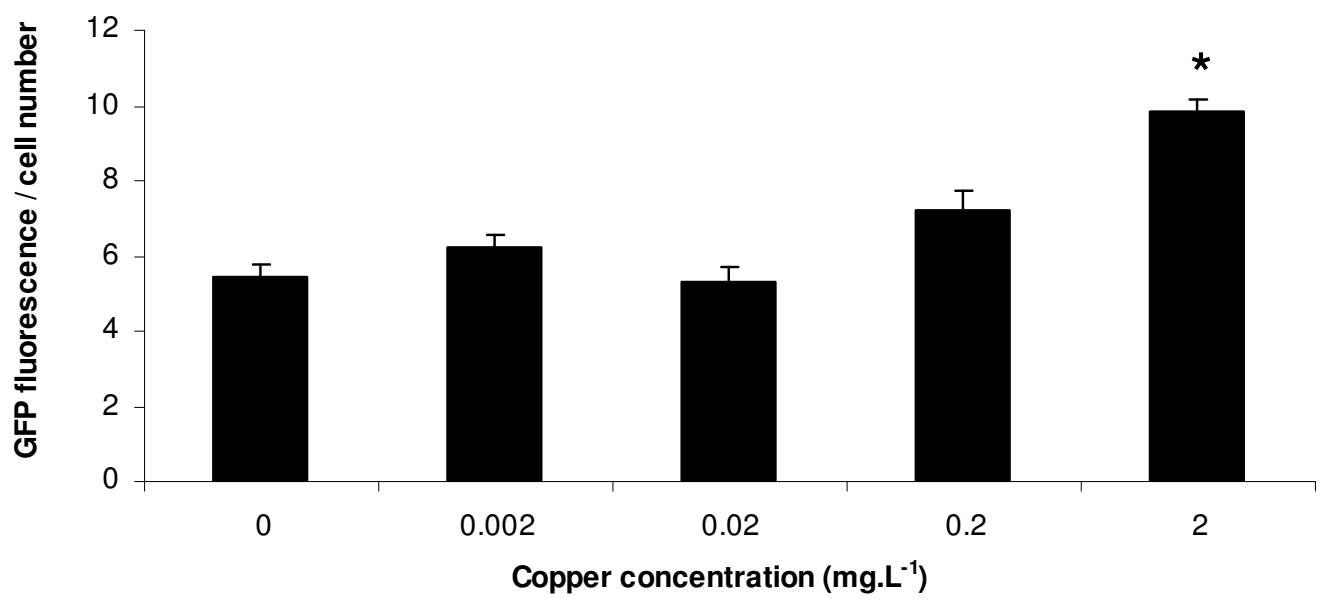

B.

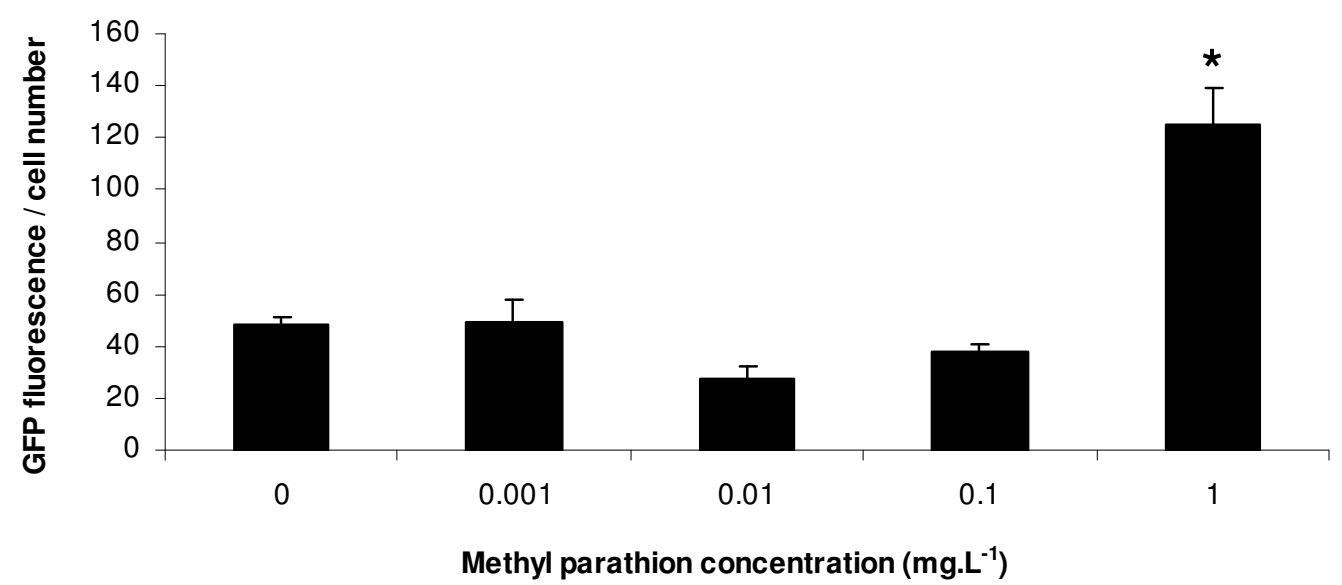

